\title{
APPLICATION OF THE FRIER DISTRIBUTED MODEL FOR ESTIMATING THE IMPACT OF LAND USE CHANGES ON THE WATER BALANCE IN SELECTED BASINS IN SLOVAKIA
}

\author{
OLIVER HORVÁT, KAMILA HLAVČOVÁ, SILVIA KOHNOVÁ, MICHAL DANKO
}

Department of Land and Water Resources Management, Slovak University of Technology, Radlinského 11, 81368 Bratislava, Slovak Republic; oliver.horvat@stuba.sk

In this study, the FRIER rainfall-runoff model with distributed parameters was developed to assess changes in runoff and water balance due to changes in land use and climate. The water balance was calculated at 3 levels: on the surface and in unsaturated and saturated zones. Six basins from the central and eastern parts of Slovakia were selected on the basis of their similar size, but different topography, land use, soil texture and climate: the upper Hornád, the upper Hron, the Poprad, the Rimava, the Slaná and the Torysa River basins. Model parameters were estimated using data from the period from June 1998 to May 2000 in daily time steps. The differences and similarities of the hydrologic processes in individual basins were investigated during the calibration period. Several scenarios of changes in land use and two simple scenarios of changes in climate were developed to estimate the impact of these changes on water balance and runoff. The changes in the hydrological regime were compared and discussed.

KEY WORDS: Land Use Change, FRIER Rainfall-Runoff Model, Distributed Parameters, Runoff and Water Balance.

Oliver Horvát, Kamila Hlavčová, Silvia Kohnová, Michal Danko: VYUŽITIE HYDROLOGICKÉHO MODELU FRIER S PRIESTOROVO ROZČLENENÝMI PARAMETRAMI NA POSÚDENIE VPLYVU ZMENY VYUŽITIA ÚZEMIA NA HYDROLOGICKÚ BILANCIU VYBRANÝCH POVODÍ NA SLOVENSKU. J. Hydrol. Hydromech., 57, 2009, 4; 27 lit., 3 obr., 4 tab.

V posledných rokoch sa vel’mi často hodnotia a diskutujú vplyvy zmien využitia krajiny a klímy na procesy hydrologickej bilancie, aj ked' miera ich vplyvu na hydrologický režim sa najmä pre komplexnost' týchto procesov vel'mi t’ažko kvantifikuje. Na odhad vplyvu zmien využitia krajiny a klímy na odtok a zložky hydrologickej bilancie bol vyvinutý zrážkovo-odtokový model FRIER s rozčlenenými parametrami. Na základe podobnej vel'kosti, ale rôznej topografie, využitia krajiny a pôdnej štruktúry bolo vybraných šest' pilotných povodí: povodie horného Hornádu, horného Hrona, Popradu, Rimavy, Slanej a Torysy. Parametre modelu boli kalibrované pre obdobie jún 1998 - máj 2000 v dennom časovom kroku. Na základe simulácií hydrologickej bilancie pre súčasný stav sa hodnotili rozdiely a podobnosti procesov tvorby odtoku v jednotlivých povodiach. Odtok a zložky hydrologickej bilancie boli následne simulované pre sedem scenárov zmien využitia krajiny a dva jednoduché scenáre zmeny zrážok a teploty vzduchu. Zmeny odtoku a hydrologickej bilancie boli porovnané a diskutované.

KLÚČOVÉ SLOVÁ: zmena využitia krajiny, zrážkovo-odtokový model FRIER, priestorovo rozčlenené parametre, odtok a hydrologická bilancia.

\section{Introduction}

The impacts of land use changes on hydrological regimes have been extensively discussed in recent years. The pressure from a rapidly increasing population in many rural areas has often caused changes in terms of deforestation, with the aim of increasing agricultural production. Changes in land cover can have an influence on a whole ecosystem, thus af- fecting the radiation and water balance (Riebsame et al., 1994), and there is no doubt that they have an effect on hydrologic processes. The problem is how to assess these impacts on a hydrologic system, which itself is very variable. In the discussion about the possible impacts on water resources from past and ongoing land use changes, it has become clear that there is a need for improved knowledge and quantitative documentation of the impact of 
changes in land use and management practice on land and water resources. Bronstert, Niehoff, Buerger (2002) summarized the current knowledge on the effects of climate and land-use change on storm runoff generation as well as the ability to model it. Also, this review discussed the fact that widespread tools for assessing how land use changes affect hydrologic processes in a basin are models with distributed parameters, which rely on a physicallybased description of the creation of the runoff and the effects of different land covers. The representation of the soil surface and the unsaturated zone is particularly important for rapid rainfall-runoff processes, and models that lump different runoff generation processes together are not suitable, especially if the effects of land-use changes are investigated (Bronstert, Niehoff, Buerger, 2002).

Physically-based rainfall-runoff models are used for a wide range of applications, such as the extension of stream flow records, the estimation of flows for ungauged basins, the prediction of the effects of land use change, and the examination of the effects of climate change. These kinds of hydrologic models have the advantage of reflecting the effects of spatially distributed model parameters such as land use on stream flows. However, our ability to assess or forecast the progress of hydrologic processes in a basin is considerably limited in spite of many models, huge databases of climatic, geologic, hydrologic and other data, and advanced technology for obtaining and processing them. Assessing the effects of land use on runoff generation is very complicated, since land use and soil cover have an effect on interception, surface retention, evapotranspiration, and resistance to overland flow. Some authors believe that truly physically-based models with distributed parameters require no calibration and take their reliability from physically based equations (Oudin et al., 2008). However, because of the complexity of runoff formation processes, scaling problems and uncertainty in estimating parameters, the existing physically-based models are still unable to function completely without calibration. In connection with this topic, representation of runoff processes and land use changes in a hydrological model are also frequently discussed (e.g., Niehoff et al., 2002; Ott, Uhlenbrook, 2004; Blöschl et al., 2007). Due to the complexity of the processes involved, the magnitude of their impact on runoff generation and subsequent flood discharges into a river system can still be highly uncertain (Niehoff et al., 2002). Beven (2001) sees a major problem in the variability of some parameters in time and space; therefore, uncertainty rises over time (see, e.g., Parkin et al., 1996; Nandakumar, Mein, 1997; Wooldridge et al., 2001).

In Slovakia, several physically-based hydrological models with distributed parameters have recently been used for assessing the impact of land use or climate change on runoff and snow melting processes and for simulating sediment transport, e.g., Wasim, Topmodel and UEB-EHZ (Kostka, Holko, 2001, 2007), WetSpa (Papánková et al., 2005; Poórová et al., 2005; Hlavčová et al., 2005), and AGNPS (Miklánek et al., 2004; Pekárová et al., 2004a, b; Pekárová, Miklánek, 2007). Holko, Kostka (2008) compared the impact of land use on runoff in mountain catchments with different scales. Changes in the speed of flood waves in the Morava River were estimated in Szolgay et al. (2008).

In this paper, changes in the runoff regime in selected basins in Slovakia due to land use changes have been estimated using the developed physically-based FRIER model with distributed parameters. Several scenarios of land use changes were created, and the impact on runoff formation was expressed by changes in the mean annual runoff and components of the water balance. Limitations of the use of distributed models for estimating land use changes are discussed.

\section{Description of the FRIER rainfall-runoff model}

Because of the complexity of runoff generation under different climate and physiographic conditions, there is a need for the relevant representation of these processes in distributed rainfall-runoff modelling. Therefore, FRIER, a physically-oriented rainfall-runoff hydrological model with distributed parameters (Horvát, 2007), was developed to simulate runoff and water balance in different regions in Slovakia. The model is based on the structure of the WetSpa model originally developed by Wang et al. (1997) and adjusted for flood prediction by $D e$ Smedt et al. (2000) and Liu et al. (2003). Several of its components were adopted in the FRIER model in order to make it more appropriate for modelling runoff from rainfall and snowmelt in several basins in Slovakia (Hlavčová et al., 2005, 2006, 2007; Horvát, 2006, 2008). The model divides a basin into uniform spatial units on a grid scale, in which the hydrological balance and the runoff simulation are calculated to the basin's outlet. The individual components of the hydrological balance are liquid 
and solid precipitation, interception, soil moisture, infiltration, actual evapotranspiration, surface runoff, interflow in the root zone, percolation into the groundwater, groundwater runoff and production of a groundwater recharge in the saturated zone. Transformation of the surface runoff in the catchment is simulated by approximating a diffusive wave model using the geometric and hydraulic characteristics of hill slopes and the stream network. The interflow and percolation of each cell is calculated using Darcy's law and a method of approximating the kinematic wave model.

The input data consist of time series of daily or hourly precipitation totals, mean daily or hourly meteorological data for computing potential evapotranspiration, mean daily or hourly discharges in a basin's outlet (for the calibration of model parameters) and the spatial layers of a digital elevation model, the soil texture and the land use of the basin. From these maps other physiographical characteristics are derived as digital maps: e.g., maps of the soil and land use parameters, flow accumulation, flow direction, the stream network, slopes and the hydraulic radius. If the data of the hourly precipitation totals is missing, it can be assessed from the daily precipitation totals, the mean hourly discharges and the air temperature. The filling in of missing data is possible but unnecessary. Missing data in a time series can either be written in an appropriate code or calculated in the model where 3 methods exist for filling them in. Data from the time series can be spatially distributed by the methods of the arithmetic mean of closest stations, nearest neighbours (Thiessen polygons), lapse rate, or kriging. Potential global radiation can be computed with or without the slope orientation of each cell and the shading of its neighboring cells. The difference between short-wave and long-wave solar radiation is expressed by the net radiation balance. Together with the surface energy balance, they are required for the determination of potential evapotranspiration. It is possible to choose among many methods, which were selected on the basis of a detailed study (Horvát, 2007), to determine potential evapotranspiration (Blaney-Criddle, Budyko, Hamon, Jensen-Haise, Mintz-Walker, Penman, Penman-Monteith, Priestley-Taylor, Schendel, Smith-Stopp, Tomlain, Turc and Turc-Wendling).

The routing parameters are generated in a newly developed extension of the ESRI ArcView GIS program in a GIS interface. Other benefits of the model are the parameterization of land use types and hydrophysical soil parameters. The values of parameters, depending on the land use types in the model, are listed in Tab. 1.

Ten global parameters serve to simplify some processes and for the best setting of the initial values. They are constants for all the cells in the basin, and they can be calibrated. Initial snow cover is assessed by parameter $S 0$, and snow melt is calculated by the degree-day method using the degreeday factor $D D$. Overland flow is estimated from accumulated rainfall excess, depression storage and the runoff coefficient using the parameter Omax. Initial soil moisture is expressed by parameter $S M O$. Interflow and percolation depend on slope, hydraulic conductivity, root depth and parameter Imax. The volume of the groundwater storage is influenced by percolation, transpiration, base flow and the parameter Gmax. The initial volume of the groundwater is estimated by the parameter $G 0$. The instantaneous unit hydrograph of the interflow is calibrated by the global parameter $I_{-} U H$, for the base flow by $B_{-} U H$. The maximum distance between a cell and stations included in the interpolation is limited by the parameter Lmax. The values of all the hydrophysical parameters can be adjusted by parameter $F G$.

Several methods for the calibration of the global parameters and also several objective functions for assessing the model's efficiency (e.g. BIAS, Nash Sutcliffe, $\operatorname{logNash}$ - Sutcliffe) are incorporated in the model.

Outputs from the FRIER model are time series of the elements of the water balance or spatial maps. The time series output contains a simulated discharge and its 3 components (overland flow, interflow and base flow) for a daily or hourly time step. The individual mean quantities for the whole basin are calculated for each time step: air temperature, potential and actual evapotranspiration, rainfall, snow melt, interception, evaporation from stored interceptions and depressions, infiltration, depression storage, evapotranspiration from the root zone, percolation, soil moisture changes, transpiration from groundwater storage, snow water equivalent, changes in stored interceptions and depressions, soil moisture and groundwater storage. The output maps can be layers of the total overland flow, interflow, base flow, actual and potential evapotranspiration, soil moisture and snow cover for each time step. 
$\mathrm{T}$ a b l e 1. Parameters depending on land use types.

T a b u l' k a 1. Parametre závisiace od druhu využitia krajiny.

\begin{tabular}{|c|c|c|c|c|c|c|c|}
\hline Land use types/Parameters & 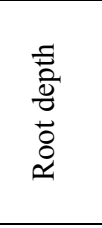 & 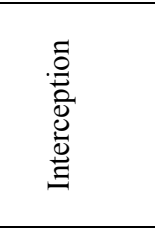 & 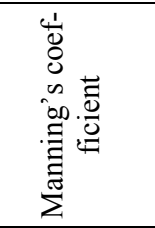 & 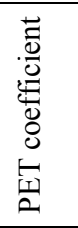 & 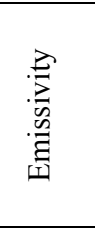 & $\begin{array}{l}\frac{8}{0} \\
0 \\
\stackrel{0}{Z}\end{array}$ & 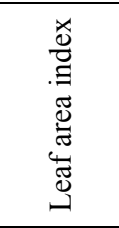 \\
\hline Units & {$[\mathrm{mm}]$} & {$[\mathrm{mm}]$} & {$\left[\mathrm{m}^{-1 / 3} \mathrm{~s}^{-1}\right]$} & {$[-]$} & {$[-]$} & {$[-]$} & {$[-]$} \\
\hline Water areas & 500 & $0.00-0.00$ & 0.04 & 1.20 & 0.950 & $0.07-0.11$ & $0.0-0.0$ \\
\hline Wetlands & 1000 & $0.00-0.50$ & 0.20 & 1.20 & 0.910 & $0.07-0.14$ & $0.5-2.0$ \\
\hline Artificial areas & 0 & $0.00-0.20$ & 0.10 & 0.90 & 0.890 & $0.08-0.30$ & $0.0-0.0$ \\
\hline Bare soils & 500 & $0.00-0.50$ & 0.02 & 0.85 & 0.910 & $0.11-0.30$ & $0.5-2.0$ \\
\hline Agricultural areas & 1000 & $0.00-1.00$ & 0.15 & 1.10 & 0.890 & $0.11-0.25$ & $0.5-6.0$ \\
\hline Meadows (short grass) & 1000 & $0.00-1.00$ & 0.20 & 1.00 & 0.980 & $0.16-0.27$ & $0.5-2.0$ \\
\hline Natural meadows (tall grass) & 1000 & $0.15-1.50$ & 0.40 & 1.05 & 0.970 & $0.22-0.31$ & $1.0-6.0$ \\
\hline Shrubs & 1000 & $0.15-1.50$ & 0.40 & 1.15 & 0.980 & $0.07-0.19$ & $5.0-6.0$ \\
\hline Transitional woodland shrubs & 1000 & $0.05-1.50$ & 0.40 & 1.15 & 0.975 & $0.16-0.27$ & $1.0-6.0$ \\
\hline Evergreen broad-leaved forests & 1500 & $0.20-2.00$ & 0.60 & 1.20 & 0.970 & $0.22-0.27$ & $5.0-6.0$ \\
\hline Deciduous broad-leaved forests & 2000 & $0.05-2.00$ & 0.80 & 1.20 & 0.970 & $0.16-0.27$ & $1.0-6.0$ \\
\hline Mixed forests & 2000 & $0.15-3.00$ & 0.60 & 1.20 & 0.975 & $0.11-0.22$ & $3.0-6.0$ \\
\hline Evergreen coniferous forests & 1500 & $0.30-4.00$ & 0.40 & 1.15 & 0.980 & $0.07-0.19$ & $5.0-6.0$ \\
\hline Deciduous coniferous forests & 1500 & $0.15-4.00$ & 0.40 & 1.15 & 0.975 & $0.11-0.19$ & $1.0-6.0$ \\
\hline
\end{tabular}

\section{Modelling runoff and water balance for the present state}

The FRIER model was applied to selected pilot basins in the central and eastern parts of Slovakia: the Upper Hornád, the Upper Hron, the Poprad, the Rimava, the Slaná and the Torysa River basins. The locations of the basins are represented in Fig. 1. The period from June 1998 to May 2000 in daily time steps was chosen for the calibration. The grid resolution was $100 \times 100 \mathrm{~m}$. The basins have a similar size but different topography, land use (Fig. 2) and soil properties.

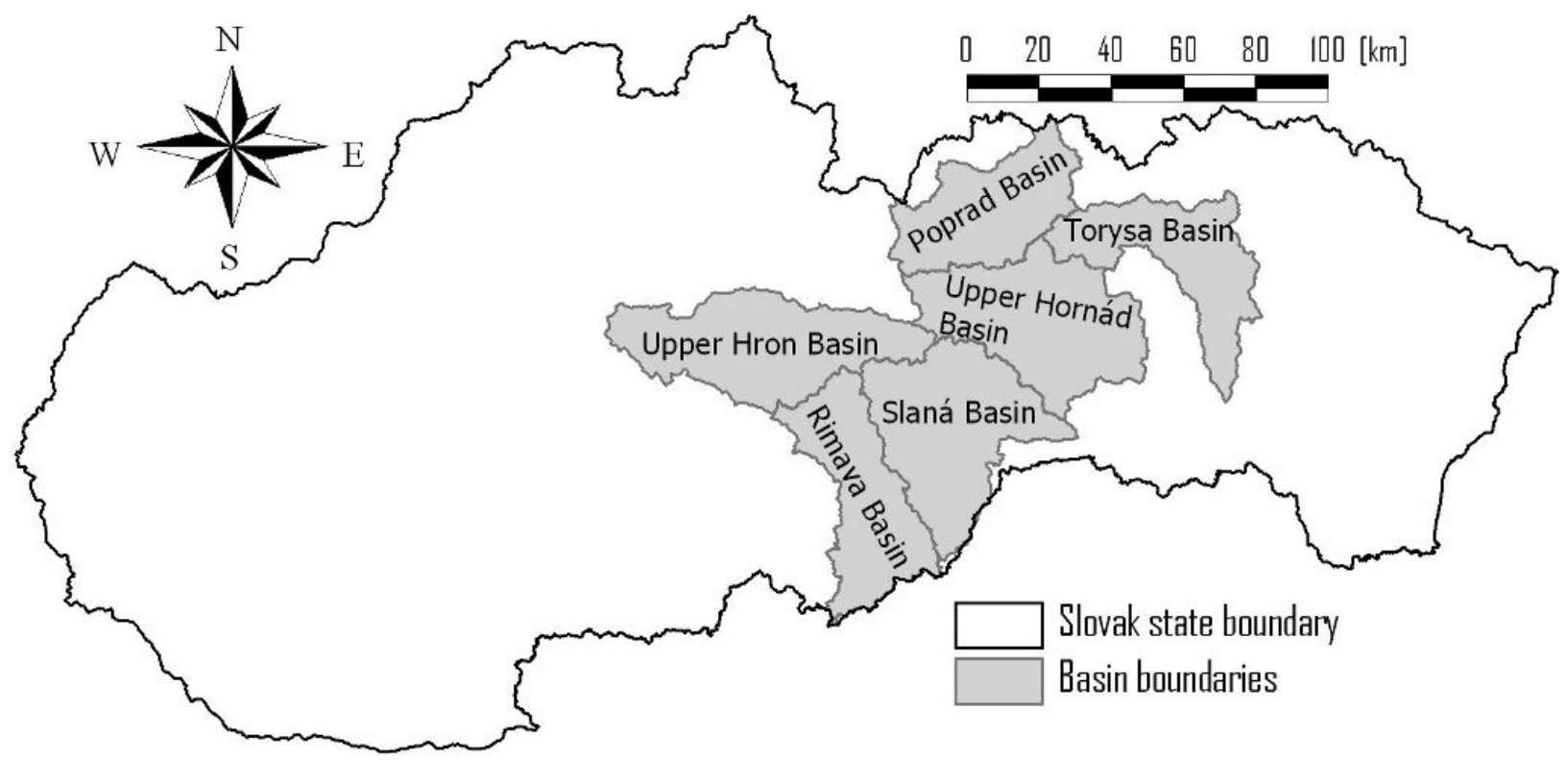

Fig. 1. Location of selected basins in Slovakia.

Obr. 1. Lokalizácia vybraných povodí na Slovensku. 


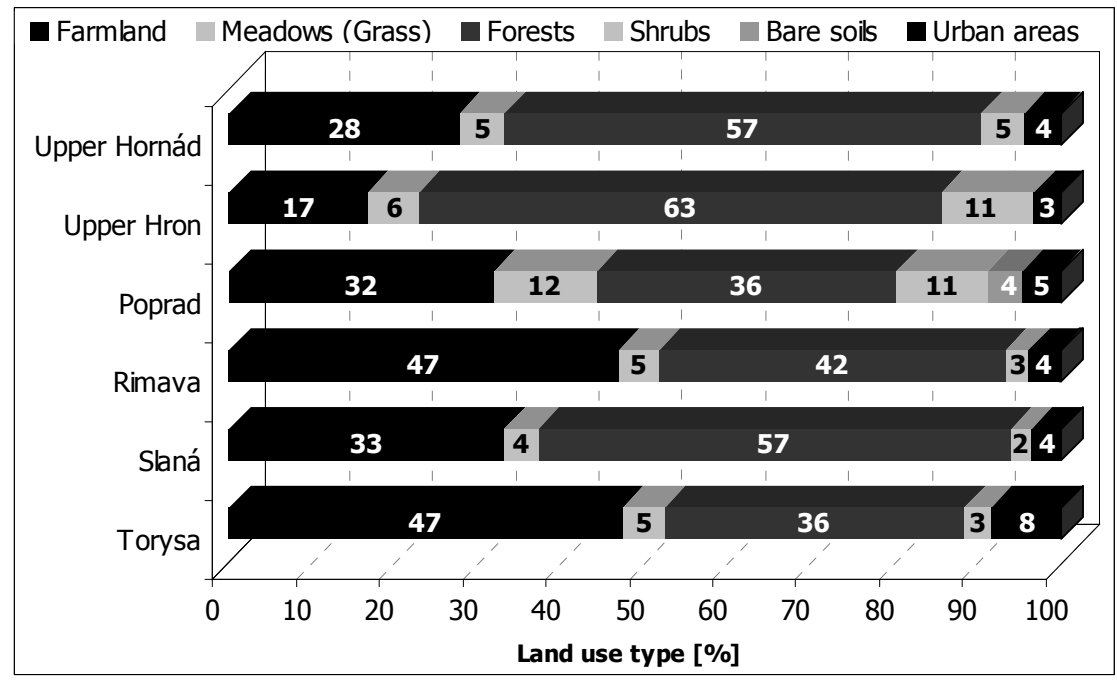

Fig. 2. Percentage of land use types in the selected basins (from the left to the right: farmland, grass, forests, shrubs, bare soils, artificial areas).

Obr. 2. Percentuálne vyjadrenie využitia krajiny vo vybraných povodiach (zlava doprava: orná pôda, lúky, lesy, kroviny, skaly, urbanizované plochy).

The Jensen-Haise method (Jensen, 1981) was used for the determination of potential evapotranspiration, except for the upper Hron River Basin, where the Mintz-Walker method was used. The shadows cast by from neighbouring hills were taken into consideration. The influence of any cloudiness was determined by Angström's parameters. The time series were interpolated by kriging except for the Rimava River Basin, where the use of the lapse rate method was more suitable.

The comparisons between the measured and simulated discharges of the selected basins for the current stage are shown in Fig. 3. The maximum peaks of the mean daily discharges are usually underestimated in simulations due to the orientation of the calibrations on the most exact determination of the water balance and its elements.

The basin area and average basin altitude, measured mean annual runoff, mean annual precipitation total, average discharge and maximum discharge (all for the calibration period), simulated average and maximum flow time (time of flow from individual cells to the basin's outlet), simulated mean annual values of runoff components and total runoff, and the simulated ratio among the runoff components (all for the calibration period) are listed in Tab. 2.

\section{Scenarios of changes in land use and climate}

In this part the FRIER model was used for esti- mating changes in runoff under changed conditions of runoff formation. Ten scenarios were developed to estimate changes in water balance due to changes in land use or climate (Fig. 6):

1. grass over forest - scenario suggesting the forest is becoming a meadow,

2. grass over farmland (agricultural areas) - scenario suggesting that the farmland be left as a meadow,

3. farmland over grass - scenario suggesting that grasslands will be cultivated,

4. dry land at the beginning - assumption of empty initial water storages and dried water areas,

5. change in forest composition - a method of changing land use towards a natural function that would be possible respecting the existing land use, i.e., urban land, farmland, etc. (further information is given in the following chapter),

6. natural land use - scenario representing a land use closest to that of a natural, pristine landscape, with almost the whole basin area covered with forest,

7. impervious urban areas - an assumption that all the urban areas are impermeable,

$8.80 \%$ of total rainfall - climatic scenario of rainfall reduction to $80 \%$ from actual observed values,

9. air temperature by $2{ }^{\circ} \mathrm{C}$ higher - climatic scenario of increase in air temperature by $2^{\circ} \mathrm{C}$. 

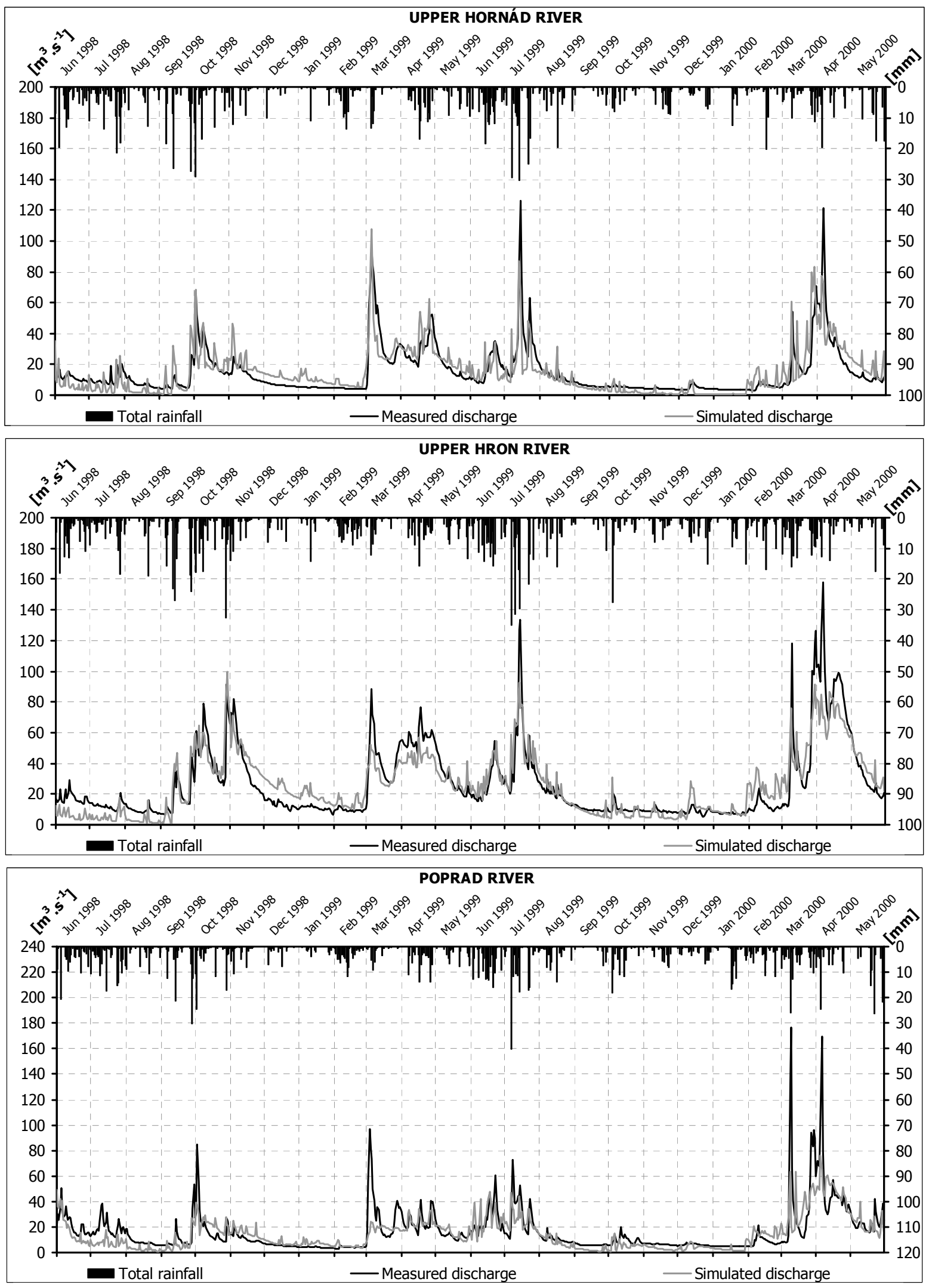

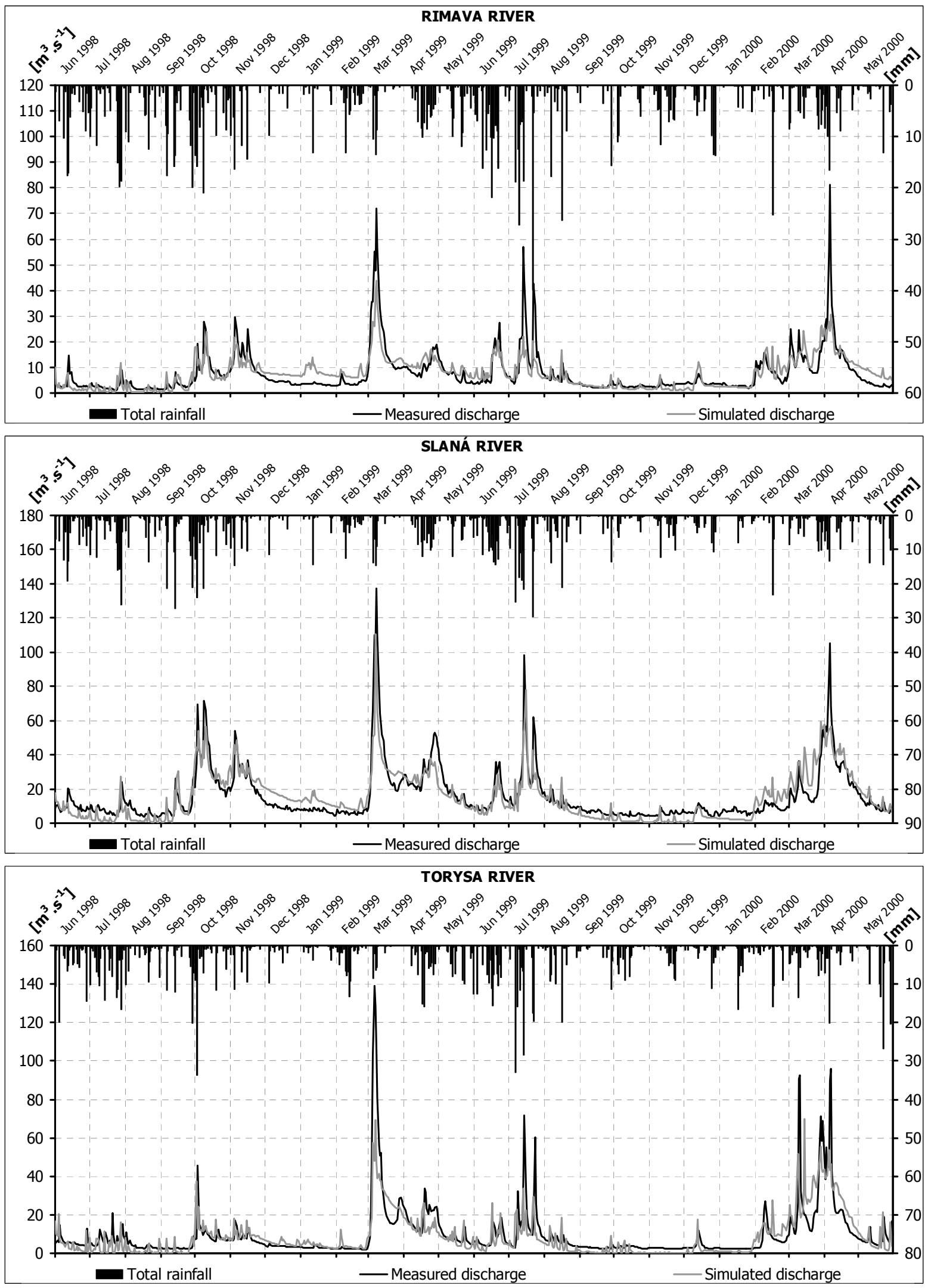

Fig. 3. Comparisons of the measured and simulated mean daily discharges from 06/1998 to $05 / 2000$ in selected basins.

Obr. 3. Porovnanie meraných a simulovaných priemerných denných prietokov v jednotlivých povodiach od 06/1998 do 05/2000. 
$\mathrm{T}$ a b 1 e 2. Selected basin characteristics and simulated runoff characteristics for the calibration period.

$\mathrm{T}$ a b u l'k a 2. Vybrané charakteristiky povodia a simulované charakteristiky odtoku pre kalibračné obdobie.

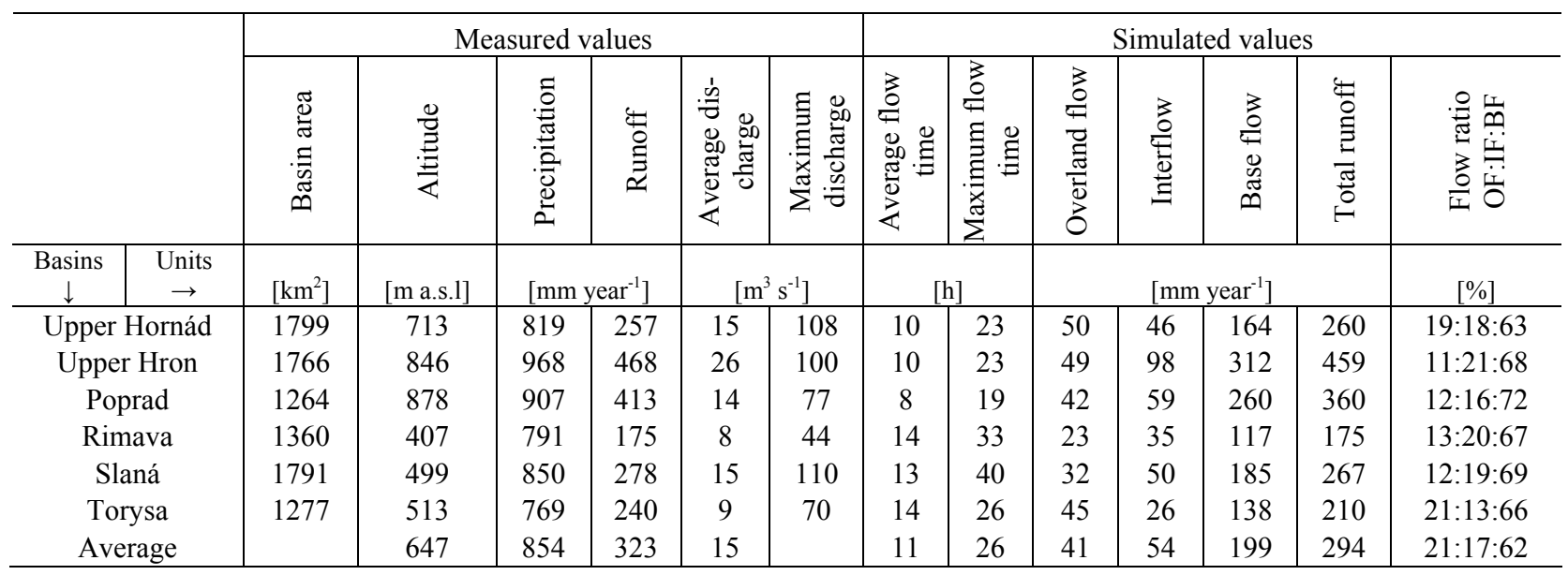

\section{Results}

The evaluation of the changes in the water balance under the scenarios is mainly oriented towards changes in total runoff and actual evapotranspiration. The changes were evaluated by comparing the simulated mean daily discharges and daily actual evapotranspiration for the actual land use and the scenarios of possible changes due to changes in land use and climate. The spatial distributions of depths of the runoff, potential and actual evapotranspiration, and soil moisture were expressed in the form of grid maps. The changes in the total runoff and actual evapotranspiration in the individual basins and as an average for the whole region are listed in Tabs. 3 and 4.

\section{Scenario 1 "Grass over forest"}

In the "Grass over forest" scenario, forests are changing to grasslands. On the one hand, the greatest increase in runoff was reached in this scenario $\left(+18 \%,+49 \mathrm{~mm} \mathrm{year}^{-1}\right.$ on average for all the basins); on the other hand, evapotranspiration decreased the most of all the land use change scenarios $\left(-6 \%,-30 \mathrm{~mm}\right.$ year $\left.^{-1}\right)$. The biggest changes in total runoff $(+26 \%)$ occurred in basins with forests as a dominant land use type, i.e., in the Slaná River Basin (57\% forest). A less intense reaction occurred in basins with a lower share of forests, i.e., in the Torysa River Basin and the Poprad River Basin (36\% forest).

$\mathrm{T}$ a $\mathrm{b}$ le 3 . Changes in the runoff in individual basins as compared to the actual stage.

$\mathrm{T}$ a b u l' k a 3. Zmeny odtoku $\mathrm{v}$ jednotlivých povodiach v porovnaní so súčasným stavom.

\begin{tabular}{|c|c|c|c|c|c|c|c|}
\hline Differences in total runoff [\%] & 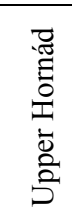 & 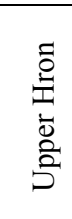 & 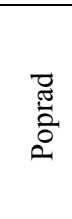 & 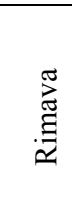 & 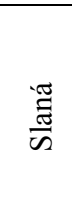 & 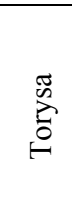 & 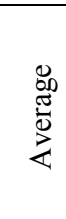 \\
\hline Present simulated runoff $\left[\mathrm{mm}\right.$ year $\left.^{-1}\right]$ & 260 & 459 & 360 & 175 & 267 & 210 & 294 \\
\hline Grass over forests & 19 & 13 & 9 & 25 & 26 & 15 & 18 \\
\hline Grass over farmland & 2 & 1 & 2 & 4 & 2 & 3 & 2 \\
\hline Farmland over grass & 0 & 0 & 0 & 0 & 0 & 0 & 0 \\
\hline Dry land at beginning & -7 & -2 & -8 & -4 & -6 & -3 & -5 \\
\hline Change in forest composition & -4 & -2 & -3 & 0 & -1 & -1 & -2 \\
\hline Natural land use & -12 & -10 & -9 & -31 & -18 & -25 & -17 \\
\hline Impervious artificial areas & 6 & 2 & 3 & 9 & 5 & 15 & 6 \\
\hline $80 \%$ of total rainfall & -37 & -30 & -31 & -40 & -36 & -36 & -35 \\
\hline Air temperature about $2^{\circ} \mathrm{C}$ higher & -12 & -8 & -6 & -14 & -11 & -12 & -10 \\
\hline
\end{tabular}


$\mathrm{T} \mathrm{a} \mathrm{b} 1 \mathrm{e}$ 4. Changes in the actual evapotranspiration in individual basins as compared to the actual stage.

$\mathrm{T}$ a b u l' k a 4. Zmeny aktuálnej evapotranspirácie $\mathrm{v}$ jednotlivých povodiach v porovnaní so súčasným stavom.

\begin{tabular}{|c|c|c|c|c|c|c|c|}
\hline Changes in actual evapotranspiration [\%] & 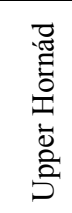 & $\begin{array}{l}\tilde{0} \\
\stackrel{0}{0} \\
\overline{\mathbf{D}} \\
\stackrel{0}{0}\end{array}$ & 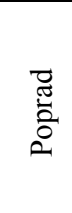 & 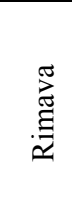 & $\frac{\widetilde{a}}{\widetilde{J}}$ & 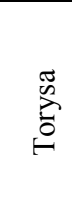 & 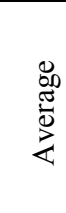 \\
\hline Present simulated runoff $\left[\mathrm{mm}\right.$ year $\left.^{-1}\right]$ & 539 & 432 & 473 & 516 & 512 & 505 & 496 \\
\hline Grass over forests & -7 & -9 & -5 & -3 & -7 & -4 & -6 \\
\hline Grass over farmland & -1 & -1 & -1 & -2 & -1 & -2 & -1 \\
\hline Farmland over grass & 0 & 0 & 0 & 0 & 0 & 0 & 0 \\
\hline Dry land at beginning & -13 & -5 & -11 & -3 & -8 & -8 & -8 \\
\hline Change in forest composition & 1 & 0 & 0 & 0 & 0 & 0 & 0 \\
\hline Natural land use & 4 & 4 & 5 & 2 & 5 & 5 & 4 \\
\hline Impervious artificial areas & -3 & -1 & -2 & -3 & -2 & -5 & -3 \\
\hline $80 \%$ of total rainfall & -11 & -11 & -11 & -15 & -13 & -13 & -12 \\
\hline Air temperature about $2^{\circ} \mathrm{C}$ higher & 8 & 11 & 9 & 6 & 7 & 7 & 8 \\
\hline
\end{tabular}

\section{Scenario 2 "Grass over farmland"}

The impact of the "Grass over farmland" scenario is most visible in the Rimava River Basin and the Torysa River Basin (the relative increase in runoff is $+4 \%,+3 \%$ respectively), in which farmland is the dominant land use type. The least amount of change appeared in the Upper Hron River Basin, where farmland occurred only on $17 \%$ of the basin's area. Generally, this scenario indicated a relatively slight impact on change in runoff. On average for all the basins, runoff increased $\left(+2 \%,+5 \mathrm{~mm}\right.$ year $\left.^{-1}\right)$, and evapotranspiration decreased $\left(-1 \%,-6 \mathrm{~mm}^{-1}\right.$ year $\left.^{-1}\right)$.

\section{Scenario 3 "Farmland over grass"}

The highest percentage of grasslands is in the Poprad River Basin (12\%); is the grasslands comprise only $5 \%$ on average in the other basins. Therefore, only small areas in the basins changed according to the "Farmland over grass" scenario. Moreover, the parameters by which farmland and grasslands are represented in the model are very similar, and thus the changes in runoff due to this scenario are low. Small differences in the individual basins were mainly caused by different types of grasslands (short vs. long grass). On average, no changes in runoff were indicated. Evapotranspiration was slightly higher by about $0.1 \%(+0.4 \mathrm{~mm}$ year $\left.^{-1}\right)$.
Scenario 4 "Dry land at the beginning"

All the initial global parameters were assumed to be equal to zero, and all the water areas were substituted for by bare soil in the "Dry land at the beginning" scenario. Empty initial groundwater storage had the most impact on runoff; in the Poprad River Basin it decreased by about $60 \mathrm{~mm}$, and it had the greatest impact on the decrease in runoff depth $\left(-8 \%,-28 \mathrm{~mm}\right.$ year $\left.^{-1}\right)$. The change in water areas to bare soil, no initial snow cover or no water in the soil affected the loss of evapotranspiration $\left(-8 \%,-41 \mathrm{~mm}\right.$ year $^{-1}$ on average), especially in the Upper Hornád River Basin $\left(-13 \%,-72 \mathrm{~mm}\right.$ year $\left.{ }^{-1}\right)$. The Rimava River Basin was only slightly affected due to the smallest deviation of the scenario from reality there.

\section{Scenario 5 "Change in forest composition"}

The solution to the "Change in forest composition" scenario was the substitution of coniferous forests by mixed forests with more natural species. The Rimava River Basin ( $0.8 \%$ coniferous forests), the Slaná River Basin (7.2\% coniferous forests) and the Torysa River Basin $(8.2 \%$ coniferous forests) have only a small amount of coniferous forests, so only slight changes in runoff occurred there. In the Upper Hornád River Basin $(37.6 \%$ coniferous forests), the Upper Hron River Basin (28.7\% coniferous forests) and the Poprad River Basin (32.4\% coniferous forests) a decrease in runoff depth of more than $8 \mathrm{~mm}^{\text {year }}{ }^{-1}$ ( $-4 \%$ and less) would occur. An increase in evapotranspiration of 
about $1 \mathrm{~mm}$ year ${ }^{-1}$ would not bring about significant changes.

\section{Scenario 6 "Natural land use"}

The "Natural land use" scenario assumes the almost complete afforestation of the basins. Changes in water balance can indeed lead to a very significant reduction in runoff $\left(-17 \%,-43 \mathrm{~mm}\right.$ year $^{-1}$ on average) together with higher evapotranspiration $\left(+4 \%,+20 \mathrm{~mm}\right.$ year $\left.^{-1}\right)$. The mean annual runoff depth decreased the most in the Rimava River Ba$\sin \left(-31 \%,-54 \mathrm{~mm}\right.$ year $\left.^{-1}\right)$ and the Torysa River Basin $\left(-25 \%,-53 \mathrm{~mm}\right.$ year $\left.^{-1}\right)$, the least in the Upper Hornád River Basin $\left(-9 \%,-32 \mathrm{~mm}\right.$ year $\left.^{-1}\right)$. Simulated impact on infiltration was especially mixed: while it increased in the Torysa River Basin $\left(+4 \%,+30 \mathrm{~mm}\right.$ year $\left.^{-1}\right)$ and the Upper Hron River Basin $\left(+0.5 \%,+3 \mathrm{~mm}\right.$ year $\left.^{-1}\right)$, it did not change in the Upper Hornád River Basin. The opposite situation occurred in the other basins (from -8 to -21 mm year $\left.{ }^{-1}\right)$.

\section{Scenario 7 "Impervious artificial surfaces"}

The assumption of the "Impervious artificial surfaces" scenario was total impermeability $(100 \%)$ of the urban areas. The greatest percentage of artificial surfaces is in the Torysa River basin (8\%); the opposite situation is in the Upper Hron River Basin $(3 \%)$, which was also reflected in the results. While the total flow increased by about $+15 \%(+31 \mathrm{~mm}$ year $^{-1}$ ) and evapotranspiration decreased by about $-5 \%\left(-25 \mathrm{~mm} \mathrm{year}^{-1}\right)$ in the Torysa River Basin, total flow increased only about $+2 \%\left(+7 \mathrm{~mm}\right.$ year $\left.^{-1}\right)$ and evapotranspiration decreased only about $-1 \%$ $\left(-6 \mathrm{~mm}\right.$ year $\left.^{-1}\right)$ in the Upper Hron River Basin. On average, the changes in the impermeability of artificial surfaces have led to an increase in runoff $\left(+6 \%, 15 \mathrm{~mm} \mathrm{year}^{-1}\right)$ and a decrease in evapotranspiration $\left(-3 \%,-13 \mathrm{~mm}^{-1}\right.$ year $\left.^{-1}\right)$.

\section{Scenario 8 "80\% of total rainfall"}

In the " $80 \%$ of total rainfall" scenario the measured mean daily rainfall totals were multiplied by a coefficient equal to 0.8 . A reduction of total rainfall of about $20 \%$ caused a runoff reduction of about 35\% (-99 mm year $\left.{ }^{-1}\right)$ and an evapotranspira- tion loss of about $12 \%\left(-61 \mathrm{~mm}^{-}\right.$year $\left.^{-1}\right)$ on average in all the basins. The biggest relative changes in runoff occurred in the Rimava River Basin $(-40 \%$, $-71 \mathrm{~mm}$ year $\left.^{-1}\right)$. The smallest runoff reductions were simulated in the Upper Hron River Basin $\left(-30 \%,-137 \mathrm{~mm}\right.$ year $\left.^{-1}\right)$ and the Poprad River Ba$\sin \left(-31 \%,-111\right.$ mm year $\left.^{-1}\right)$.

\section{Scenario 9 "Air temperature about $2{ }^{\circ} \mathrm{C}$ higher"}

In the "Air temperature about $2{ }^{\circ} \mathrm{C}$ higher scenario" all the measured values of mean daily air temperature increased by about $2{ }^{\circ} \mathrm{C}$. An anticipated increase in evapotranspiration $(+8 \%,+39 \mathrm{~mm}$ year ${ }^{-1}$ on average) caused a reduction in runoff $\left(-10 \%,-28 \mathrm{~mm}\right.$ year $\left.^{-1}\right)$. The biggest changes were recorded in the Rimava River Basin where the total flow decreased by about $14 \%\left(-25 \mathrm{~mm}\right.$ year $\left.^{-1}\right)$, and in the Upper Hron River Basin, where evapotranspiration increased by about $11 \%\left(+48 \mathrm{~mm}\right.$ year $\left.^{-1}\right)$.

\section{Conclusions}

The results achieved in the study suggest how various sensitive components of simulated runoff and water balance in selected basins react to changes in land cover (or climate characteristics). The methodology can be used in integrated water resources management, especially for organizing land use and assessing the impact of land use changes on the runoff in a catchment. However, the reliability of the results depends largely upon the availability and quality of the input data, the extent of the schematization of the processes represented by the model, the parameterization of the environmental characteristics for the simulated physical processes and the global parameters of the calibrated model. All the components of water balance and runoff components such as overland flow, interflow and baseflow are only simulated, and they were not validated with measured data. Also because of the absence of direct experiments with land use changes in the modelled catchments, the modelling results can only be confronted with results from experimental catchments, other modelling studies, expert judgments, and validation of the model with other data and in different basins.

Acknowledgements. This work was supported by the Slovak Research and Development Agency 
under Contract No. APVT-0378-07, LPP-0254-07 and VEGA Agency Project No. 2/0096/08.

\section{REFERENCES}

BEVEN K.J., 2001: Rainfall-Runoff Modelling. The Primer. John Wiley \& Sons, Ltd., Chichester, 360 pp.

BLÖSCHL G., ARDOIN-BARDIN S., BONELL M., DORNINGER M, GOODRICH D., GUTKNECHT D., MATAMOROS D., MERZ B., SHAND P., SZOLGAY J., 2007: At what scales do climate variability \& land cover change impact on flooding and low flows? Hydrological Processes, 21, 1241-1247.

BRONSTERT A., NIEHOFF D., BUERGER G., 2002: Effects of climate and land-use change on storm runoff generation: present knowledge and modeling capabilities. Hydrological Processes, 16, 2, 509-529.

DE SMEDT F., LIU Y.B., GEBREMESKEL S., 2000: Hydrological modeling on a catchment scale using GIS and remote sensed land use information. In: Brebbia, C.A. (ed.) Risk analysis II. WTI, Boston, 295-304.

HORVÁT O., 2007: Parameterization of Hydrologic Processes in Runoff Modelling. PhD. Thesis in Hydrology and Water Management, Department of Land and Water Resources Management, Faculty of Civil Engineering, Slovak University of Technology in Bratislava, $129 \mathrm{pp}$.

HORVÁT O., 2008: Description of the FRIER rainfall-runoff model. Podzemná voda, 14, 1, 37-45.

HLAVČOVÁ K., SZOLGAY J., KOHNOVÁ S., PAPÁNKOVÁ Z., HORVÁT O., 2005: On the possibility of assessment of land use change impact on runoff with a hydrological model with distributed parameters. Meteorological J., 8, 73-81.

HLAVČOVÁ K., SZOLGAY J., KOHNOVÁ S., HORVÁT O., PAPÁNKOVÁ Z., 2006: Parameterization of land-use characteristics in distributed rainfall-runoff modelling. Meteorological J., 9, 131-138.

HLAVČOVÁ K., HORVÁT O., SZOLGAY J., DANKO M., KOHNOVÁ S., 2007: Scenarios of land use changes and simulations of hydrological responses in the Poprad River basin. Meteorological J., 10, 4, 199-203.

HOLKO L, KOSTKA Z., 2008: Impact of land use on runoff in mountain catchments of different scales. Soil and Water Res., 3, 3, 113-120.

JENSEN M. E., 1981: Design and Operation of Farm Irrigation Systems. An ASAE Monograph, No. 3. American Society of Agricultural Engineers, Michigan, 189-219.

KOSTKA Z., HOLKO L, 2001: Runoff Modelling in a Mountain Catchment with Conspicuous Relief Using TOPMODEL. J. Hydrol. Hydromech., 49, 3-4, 149-171.

KOSTKA Z., HOLKO L, 2007: Effect of land use change on hydrological regime in the upper Váh river catchment. Meteorological J., 10, 193-197.

LIU Y.B., GEBREMESKEL S., DE SMEDT F., HOFFMANN L., PFISTER L., 2003: A diffusive transport approach for flow routing in GIS-based flood modeling. J. of Hydrology, 283, 91-106.

MIKLÁNEK P., PEKÁROVÁ P., KONÍČEK A., PEKÁR J., 2004: Use of a distributed erosion model [AGNPS] for planning small reservoirs in the Upper Torysa basin. Hydrology and Earth System Sciences, 8, 6, 1186-1192.
NANDAKUMAR N., MEIN R.G., 1997: Uncertainty in rainfall-runoff model simulations and the implications for predicting the hydrologic effects of land-use change. J. of Hydrology, 192, 211-232.

NIEHOFF D., FRITSCH U., BRONSTERT A., 2002: Landuse impacts on storm-runoff generation: Scenarios of landuse change and simulation of hydrological response in a meso-scale catchment in SW-Germany. J. of Hydrology, 267, 80-93.

OTT B., UHLENBROOK S., 2004: Quantifying the impact of land use changes at the event and seasonal time scale using a process-oriented catchment model. Hydrology and Earth System Science, 8, 1, 62-78.

OUDIN L., ANDRÉASSIAN V., LERAT J., MICHEL C., 2008: Has land cover a significant impact on mean annual stream flow? An international assessment using 1508 catchments. J. of Hydrology, 357, 303-316.

PAPÁNKOVÁ Z., HORVÁT O., HLAVČOVÁ K., SZOLGAY J., KOHNOVÁ S., 2005: Scenarios of changes in flood regime due to land use change in the Hron River basin. In: Marsalek J., (ed.): Transboundary Floods: Reducing Risk and Enhancing Security through Improved Flood Management Planning. NATO Advanced Research Workshop. TREIRA, S.R.L., Oradea, Romania, 193-205.

PARKIN G., O'DONNELL G., EWEN J., BATHURST J.C., O CONNELL P.E., LAVABRE J., 1996: Validation of catchment models for predicting land-use and climate change impacts. 2. Case Study for a Mediterranean Catchment. J. of Hydrology, 175, 595-613.

PEKÁROVÁ P., KONÍČEK A., MIKLÁNEK P., STANČÍK Š., 2004a: Lifespan estimation of the considered sediment trapping ponds in the upper Torysa basin using the AGNPS model (Part I. Rainfall scenario creation.) (In Slovak.) Acta Hydrologica Slovaca, 5, 2, 286-292.

PEKÁROVÁ P., SVOBODA A., MIKLÁNEK P., KONÍČEK A., PEKÁR J., 2004b: Lifespan estimation of the considered sediment trapping ponds in the upper Torysa basin using the AGNPS model (Part I. Simulation results). (In Slovak.) Acta Hydrologica Slovaca, 5, 2, 293-301.

PEKÁROVÁ P., MIKLÁNEK P., 2007: Influence of forest on snowmelt runoff in small highland basins in Slovakia. Series Geographica - Physica, 37-38, 1, 51-62.

POÓROVÁ J., VELČICKÁ L., KUNÍKOVÁ E., DE SMEDT F., BAHREMAND A., CORLUY J., LIU Y-B., 2005: Assessing impact of land use on floods using the WetSpa model. J. Hydrol. Hydromech., 53, 4, 253-266.

RIEBSAME W.E., MEYER W.E., TURNER B.L., 1994: Modelling land use and cover as part of global environmental change. Clim. Change, 28, 45-64.

SZOLGAY J., DANÁČOVÁ M., JURČÁK S., SPAL P., 2008: Multilinear flood routing using empirical wave-speed discharge relationships: Case study on the Morava River. J. Hydrol. Hydromech., 56, 4, 213-227.

WOOLDRIDGE S., KALMA J., KUCZERA G., 2001: Parametrization of a simple semi-distributed model for assessing the impact of land-use on hydrologic response. J. of Hydrology, 254, 16-32.

Received 19 February 2009 Scientific paper accepted 9 June 2009 


\section{VYUŽITIE HYDROLOGICKÉHO MODELU FRIER S PRIESTOROVO ROZČLENENÝMI \\ PARAMETRAMI NA POSÚDENIE VPLYVU ZMENY VYUŽITIA ÚZEMIA NA HYDROLOGICKÚ BILANCIU VYBRANÝCH POVODÍ NA SLOVENSKU}

Oliver Horvát, Kamila Hlavčová,

Silvia Kohnová, Michal Danko

V posledných rokoch sa vel'mi často hodnotia a diskutujú dôsledky zmien využitia krajiny a klímy na procesy hydrologickej bilancie, aj ked' miera ich vplyvu na hydrologický režim sa najmä pre komplexnost' týchto procesov vel'mi t’ažko kvantifikuje. Na odhad vplyvu zmien využitia krajiny a klímy na odtok a prvky hydrologickej bilancie sme použili zrážkovo-odtokový model FRIER s rozčlenenými parametrami (Horvát, 2007), ktorý bol vyvinutý na modelovanie odtoku a hydrologickej bilancie v rôznych regiónoch Slovenska. Model vychádza zo štruktúry modelu WetSpa (Wang a kol., 1997), mnohé jeho zložky však boli v modeli FRIER modifikované alebo zmenené tak, aby bol model vhodný na simulovanie odtoku zo zrážok a topenia sa snehu v našich podmienkach (Hlavčová et al., 2005, 2006, 2007; Horvát, 2006, 2008). Povodie je v modeli rozdelené na rovnomerné štvorcové jednotky, v ktorých sa modelujú zložky vertikálnej hydrologickej bilancie a z ktorých sa odtok následne transformuje do záverečného profilu povodia. Simulované prvky hydrologickej bilancie tvoria tekuté a snehové zrážky, intercepcia, akumulácia a topenie snehu, infiltrácia, pôdna vlhkost', evapotranspirácia, povrchový, podpovrchový, podzemný a celkový odtok. Transformácia odtoku na povodí vychádza z predpokladu aproximácie difúznej vlny, s využitím geometrických a hydraulických charakteristík svahov a riečnej siete.

Vstupné údaje do modelu tvoria časové rady denných alebo hodinových úhrnov zrážok, priemerné denné alebo hodinové hodnoty teploty vzduchu a d'alších klimatických prvkov pre výpočet potenciálnej evapotranspirácie. Pre kalibráciu modelu sú potrebné merané hodnoty priemerných denných alebo hodinových prietokov $\mathrm{v}$ záverečnom profile povodia. Priestorové vstupné údaje predstavujú digitálny model reliéfu, mapa pôdnych druhov a mapa využitia územia. $Z$ týchto vrstiev sa odvodzujú priestorovo rozčlenené parametre modelu, ako sú mapa sklonov, smerov a akumulácie odtoku, hydraulického polomeru, mapy hydrofyzikálnych vlastností pôdy, mapa koeficientu drsnosti, listovej plochy, híbky koreňovej zóny, kapacity intercepcie a pod. Model obsahuje tiež 10 parametrov, ktoré nie sú priestorovo premenlivé a v modeli sa kalibrujú.

Na základe podobnej vel'kosti, ale rôznej topografie, využitia krajiny a pôdnych vlastností bolo pre simulácie vybraných šest' pilotných povodí, a to povodie horného Hornádu, horného Hrona, Popradu, Rimavy, Slanej a Torysy. Pre tieto povodia boli parametre modelu kalib- rované pre obdobie jún 1998 - máj 2000 v dennom časovom kroku. Na základe simulácií odtoku a prvkov hydrologickej bilancie pre súčasný stav boli zhodnotené rozdiely a podobnosti procesov tvorby odtoku $\mathrm{v}$ jednotlivých povodiach.

Následne bolo vytvorených 7 scenárov zmenených podmienok spôsobu využivania územia a 2 jednoduché scenáre zmenených klimatických charakteristík. Simulované zmeny celkového odtoku a aktuálnej evapotranspirácie pre jednotlivé scenáre oproti súčasnému stavu sú vyjadrené v tab. 3 a 4.

Scenár, pri ktorom sa predpokladala zmena lesných porastov na trávu, sa prejavil pomerne výrazným zvýšením celkového priemerného ročného odtoku $(+18 \%$, $+49 \mathrm{~mm}$ rok $^{-1} \mathrm{v}$ priemere pre všetky povodia) a poklesom aktuálnej evapotranspirácie $\left(-6 \%,-30 \mathrm{~mm}\right.$ rok $\left.^{-1}\right)$. Najväčšie zmeny sa pritom prejavili v povodiach, kde sú lesy dominantným porastom, napr. v povodí Slanej, kde lesné porasty pokrývajú $57 \%$ plochy povodia.

Scenáre, pri ktorých sa predpokladala zmena ornej pôdy na trávu a naopak, zmena trávnatých porastov na ornú pôdu, sa prejavili iba miernou zmenou celkového odtoku a aktuálnej evapotranspirácie. Tento výsledok bol spôsobený najmä skutočnost'ou, že parametre, ktorými je v modeli vyjadrená orná pôda a tráva, sú vel'mi podobné. Miera citlivosti jednotlivých povodí na zmeny podla uvedených scenárov závisela pritom najmä od plochy trávnatých porastov a ornej pôdy $\mathrm{v}$ jednotlivých povodiach.

Podobný nevýrazný vplyv na odtok sa prejavil aj pri scenári, ked' bolo zmenené zloženie lesa, a to tak, že ihličnaté lesy boli nahradené lesmi zmiešanými. Tento výsledok znova súvisí s malými rozdielmi medzi parametrami ihličnatého a listnatého lesa $v$ modeli.

Pomerne výrazným znížením celkového odtoku sa prejavil scenár predstavujúci prirodzenú krajinu, ked'sa predpokladalo takmer úplné zalesnenie jednotlivých povodí. Celkový priemerný ročný odtok sa vo všetkých povodiach znížil v priemere o $-17 \%,-43 \mathrm{~mm}$ rok $^{-1}$, pričom aktuálna priemerná ročná evapotranspirácia sa zvýšila v priemere o $+4 \%,+20 \mathrm{~mm}^{\text {rok }}{ }^{-1}$. Najvýraznejšie zníženie odtoku sa prejavilo $\mathrm{v}$ povodí Rimavy $\left(-31 \%,-54 \mathrm{~mm} \mathrm{rok}^{-1}\right)$ a Torysy $\left(-25 \%,-53 \mathrm{~mm} \mathrm{rok}^{-1}\right)$.

Scenár založený na predpoklade predchádzajúceho sucha, ked' boli nastavené nulové hodnoty počiatočnej vlhkosti pôdy na začiatku simulácií, sa prejavil miernym znížením celkového priemerného ročného odtoku, ako aj znížením priemernej ročnej evapotranspirácie. Scenár, pri ktorom sa predpokladala zmena všetkých plôch v urbanizovaných územiach na nepriepustné, sa prejavil nárastom priemerného ročného odtoku $\mathrm{v}$ priemere $\mathrm{o}$ $+15 \%,+31 \mathrm{~mm}^{-1}$ rok $^{-1}$ a znížením priemernej ročnej evapotranspirácie.

Obidva jednoduché scenáre zmenených klimatických charakteristík sa prejavili podl'a očakávania znížením priemerného ročného odtoku. Zníženie zrážok o $20 \%$ predstavovalo zníženie priemerného ročného odtoku v priemere o $35 \%,-99 \mathrm{~mm} \mathrm{rok}^{-1}$ a zvýšenie teploty 
vzduchu sa prejavilo zvýšením aktuálnej evapotranspirácie (v priemere o $+8 \%,+39 \mathrm{~mm} \mathrm{rok}^{-1}$ ) a znížením priemerného ročného odtoku ( $\mathrm{v}$ priemere $\mathrm{o}-10 \%,-28 \mathrm{~mm}$ $\left.\operatorname{rok}^{-1}\right)$.

Dosiahnuté výsledky umožňujú posúdit', ako citlivo reaguje simulovaný odtok a jeho zložky, ako aj d'alšie prvky hydrologickej bilancie na zmenu využitia územia (ako aj na zmenu klimatických charakteristík). Výsledky simulácí́ odtoku modelom $\mathrm{s}$ priestorovo rozčlenenými parametrami možno použit' vo vodnom hospodárstve, v plánovaní krajiny a v integrovanom manažmente povodia. Stále však treba mat' na pamäti aj neistoty, spojené s týmto prístupom. Výsledky modelovania sú vo vel'kej miere závislé od disponibility vstupných údajov, parametrizácie spôsobu využitia územia a jednotlivých druhov porastov v modeli, ako aj schematizácie simulovaných procesov v modeli. Problémom zostáva aj skutočnost', že parametre modelu sú kalibrované na zhodu medzi meranými a simulovanými prietokmi v záverečnom profile povodia, všetky ostatné prvky hydrologickej bilancie sú iba simulované a nie sú overené meranými hodnotami. Výsledky modelovania je preto potrebné interpretovat' $\mathrm{s}$ dostatočnou opatrnost'ou a konfrontovat' $\mathrm{s}$ d’alšími výsledkami z literatúry a experimentálnych meraní. 